\title{
The Joint Command and Staff Course: responding to the educational needs of senior officers in the Irish Defence Forces.
}

\section{Colin Lawlor}

The Defence Forces are Ireland's military instrument of national power with responsibilities for national security and defence. The Irish government is committed to supporting international peace and security by deploying Defence Forces' personnel on United Nations peacekeeping missions and EU and NATO-led crisis management operations. However, the characteristics of the contemporary operating environment (COE) make military operations today more complex than at any other time in human history. To operate effectively in the COE requires officers that are educated to cope with uncertainty and have highly developed critical thinking skills. This article examines the Defence Force's response to the challenge of educating its senior leaders through the recently developed Joint Command and Staff Course delivered in partnership with Maynooth University. This paper advances the argument that developing its personnel's intellectual capacities is essential for the Defence Forces to operate effectively in the uncertainty of the modern security environment.

Military organisations persistently search for ways to improve how they learn. Jung (2009) believes that learning and adaptation are vital to preparing military organisations for future challenges. He claims that "if we were to choose merely one advantage over our adversaries, it would certainly be the following: to be superior in the art of learning and adapting" (p. 359). Similarly, General Martin Dempsey, former Chief of the US Army, claims that "we have to learn faster and better than our future adversaries. Stated a bit differently, we must prevail in the competitive security environment" (Dempsey, 2011, p. i). Ryan (2019) identifies four areas of military advantage "geographic, technological, mass, and intellectual" (p. 29). He argues that individual and institutional "intellectual edge" is essential for achieving military objectives in the $21^{\text {st }}$ century. Professional Military Education (PME) is necessary for developing an intellectual advantage. This paper argues that developing its personnel's intellectual capacities is essential for the Defence Forces to achieve its strategic end state of becoming a "flexible, deployable, 
sustainable, interoperable and adaptable" military force (Defence Forces, 2016). A better educated force can mitigate the complexity of the environments where the Defence Forces operate. This paper focuses primarily on senior officer education at The Command and Staff School, which has been the vanguard of the Defence Forces' education collaboration with higher education since the early 2000 s.

In the first section, the COE is described to provide the context in which the Defence Forces must be prepared to operate. The second section traces senior officer education evolution since the Cold War and its influence on the Command and Staff School's educational engagement with higher education institutions. Finally, the paper provides an overview of the new Joint Command and Staff Course inaugurated in 2018.

\section{The Context}

Sir John Adams pointed out in his 1922 book titled Modern Developments in Educational Practice that "It seems inherent in human beings to regard their own period as one of notable change. We are continually telling each other that this is a critical time" (cited in Cairns \& Malloch, 2011, p. 2). This is indeed true of the literature that describes the military operating environment, where each era presents change and unique challenges. Strategic theory can help us to understand why this is the case. On War is a treatise about war and military strategy written by Prussian General Carl von Clausewitz (1780-1831). In his magnus opus, Clausewitz presents a systematic account of the theory and philosophy of war. While based mainly upon the Prussian Army's experiences of the Napoleonic Wars, On War continues to influence Western military strategic thought and military education today. This work is helpful for military and political science students to understand the nature and character of today's operating environment.

Clausewitz considers the fundamental nature of war to be a political instrument that "is merely the continuation of policy by other means" (von Clausewitz, 1993, p. 99). War exists, therefore, to achieve political purposes. Clausewitz explains that "the political objective is the goal, war is the means of achieving it" (ibid). The nature of war relates to political objectives, and this has not changed throughout history. The difference between the nature and the character of war is succinctly explained in the British Army Doctrine Primer (published in 2011): "War has two components that endure: its nature (the objective) remains constant under all circumstances; while its character (the subjective) alters according to context." (Minister of Defence, 2011, pp. 4-3). This means that the character of war constantly changes, which Clausewitz likens to a chameleon adapting to its surroundings. He points out that "Every age has its own kind of war, its own limiting conditions, and its own peculiar preconceptions. Each period, therefore, would have held to its own theory of war" (von Clausewitz, 1993, p. 593). War, therefore, reflects the world from which it emanates (Sheehan, 2013). Thus, military education curricula must be responsive to modern developments in technology, thinking, and approaches while remaining true to the fundamental principles of military operations (Davidson \& Tsakissiris, 2020). 
Today's globalised world is characterised by "complexity, interconnectedness, pluralism, and uncertainty" (Head \& Alford, 2015, p. 715). The constantly changing character of war presents a significant challenge to military education institutions charged with preparing personnel to deploy in this environment. The Irish Defence Forces operate in environments that span the full security spectrum from peace to conflict through to war. The Defence Forces are currently deployed on Peace Support Operations (PSOs) in Africa, the Middle East, and Eastern Europe. In these theatres, Defence Forces' personnel face a combination of security threats "which are more diverse, less visible and less predictable" than before (European Union, 2003. Department of Defence, 2019). Jacky Hong suggests that defining and understanding the complexity of the environment is crucial for organisational survival (Hong, 1999). Therefore, the environment where militaries operate must be defined and understood to develop a suitable education and training strategy. In the next section, the key features of the operating environment are identified.

\section{Defining the contemporary operating environment}

The oft-quoted Kilcullen (2009) notes that the threat environment faced by militaries today "is nothing if not complex, ambiguous, dynamic, and multifaceted, making it impossible to describe through a single model" (Kilcullen, 2009, p. 7). Peter Vaill coined the term "white water conditions" to describe conditions characterised by: surprises, novel ill-structured problems, costly events, and where issues are not solved systematically (Vaill, 1996). Ronald Barnett uses the term 'supercomplexity' to explain how we can no longer describe or even understand the world we live in (Barnett, 2012). While Grint (2005) categorises the problems generated by these security conditions as wicked problems. A wicked problem is defined as:

complex, rather than just complicated, it is often intractable, there is no unilinear solution, moreover, there is no stopping point, it is novel, an apparent solution often generates other problems, and there is no right or wrong answer, but there are better or worse alternatives.

(Grint, 2005, p. 1473)

The COE is certainly supercomplex and is beset by wicked problems. How to effectively educate a large organisation to deal with the supercomplexity posed by the 'white water conditions' of these environments could be considered as a classic 'wicked problem' in itself as there is no definitive correct answer. However, there are certainly better or worse alternatives. The worst alternative, in this case, is for the military education curriculum to remain static. Instead, military education needs to constantly evolve in response to the operational challenges its personnel face. The following section focuses on the Defence Forces' educational response and traces how senior officer education has evolved over the past thirty years.

\section{Educating senior officers for complexity}

The Military College is the institution responsible for preparing Defence Forces personnel for working in the modern security environment. It plays a pivotal role in delivering training, education, and doctrine to the Defence Forces and its combat units (Defence Forces, 2021). It is 
where officers complete their Professional Military Education (PME) throughout their careers, culminating with senior-level command and staff education. Military education plays a vital role in developing a broad spectrum of national military capabilities. These capabilities allow the Irish government to project military power in response to security or national disaster crises in domestic and international settings, supporting government security and foreign policy objectives. In the performance of its role both nationally and internationally, the Defence Forces operate in what Paananen and Pulkka $(2019$, p. 1) call an "ever-changing complex, multilevel operational environment". The characteristics of the COE make military operations today more complex than at any other time in human history. The literature is replete with definitions and theories on the character of modern warfare, and it is now a well-understood phenomenon. However, educating military organisations such as the Defence Forces to operate effectively in this environment is less well understood. Morgan-Owen (2018) argues that military education is now more critical than ever before because modern militaries face increasingly complex and uncertain operating conditions. This changing environment presents significant challenges for small armed forces such as the Defence Forces engaged in peace support and crisis management operations in some of the world's most volatile environments (Department of Defence, 2019). As the White Paper on Defence 2015 outlines, pan-European threats such as terrorism, weapons of mass destruction, regional conflicts (especially on the borders of Europe) and organised crime present serious security challenges for defence and security (Department of Defence, 2015). The point was reinforced by the 2019 White Paper Update (Department of Defence, 2019). For the Defence Forces to retain the ability to effectively operate within complex environments both at home and overseas requires a flexible and adaptable force, with well-educated senior leaders capable of critical thinking and problem-solving. The military education curricula, therefore, cannot remain static. It must be constantly under review and adapt and change in response to its learners' professional and educational needs.

\section{Post-Cold War military education in Europe}

Foot (2001, p. 12) argues that "European professional military education was profoundly conservative" during the Cold War period, and military academies were characterised by insularity rather than the development of innovative thought to address security challenges. He points out that the priority was on maintaining the strategic status quo. Similarly, Utting (2009) notes that in the Cold War era "PME tended towards training: a predicted response to a predictable situation" (p. 313). Trefry (1992) posits that military training is primarily focused on teaching how something is done. Training focuses on developing competence in a procedure or task without considering why something is done. Training creates a standardised response to a particular set of conditions and develops military skills and drills. The training focus prevailed in PME for some time after the Cold War, as traditional approaches to military education were comfortable with the certainty of right and wrong answers.

Foot (2001) identifies the mid-1990s as a turning point in military education where a new educational approach emerged, which he called the 'Kosovo model'. This approach focused on educating officers for "operational complexity" and also educating them for "political ambiguity" (p. 15). Jung (2009, p. 355) points out that "[the] world of conflict is no longer a simple blue 
versus red equation, but increasingly a blue versus red versus green versus orange me'lange". The changing operational environment required that approaches to training and education for military officers also had to change. In response, staff colleges needed to change how they were organised and operated. This saw military and academic staff work together to deliver postgraduate level PME, externally accredited by a university. The focus shifted from training to an education oriented curriculum, intending to develop learners academic ability to think critically and make informed ethical decisions. Barrett (2009) posits that there has been a demand for higher academic standards within military education institutions since the Cold War ended. He believes that this "has led to a vision of the staff college in particular as a post-graduate institution" that can award masters level degrees (p. 2).

Developments in higher education in Europe in the early 2000s further influenced military education. Callado-Munoz and Utrero-Gonzalez (2019) believe that European military education exploited the opportunities provided by the Bologna Declaration to "renew itself and to improve its academic standards" (p. 2). Changes to the European higher education landscape in the early 2000 s led to the adoption of enhanced academic standards in military institutions, the development of continuing professional military education, and the expansion of international collaboration for military education (Libel, 2019). The early 2000s saw an increase in academic and military partnerships for the delivery of PME, and the award of academic qualifications for the completion of staff courses became the norm throughout Europe.

\section{Developments in Ireland}

Prior to 2003, senior leaders in the Defence Forces were educated primarily through the Senior Command and Staff Course. This was a nine-month-long residential career course conducted annually at the Command and Staff School in the Military College. The course aimed:

To qualify officers of all service corps to hold the rank of Lieutenant Colonel and higher rank, to command formations of all components of the Defence Forces and to perform the higher staff work involved in the handling of such formations.

(DFR CS 3, Part 1, Para 6 (ii)).

The course was mainly delivered by 'in-house' military instructors and focused on mastering Brigade-level tactics using the Military Decision Making Process (MDMP) ${ }^{1}$ to solve land-based tactical problems. The course also had some academic elements in subject areas such as international relations, defence studies, leadership and management, and military history. Since the late 1990s, the Command and Staff School have cultivated relationships with equivalent staff colleges worldwide that saw Irish officers attend Command and Staff Courses at Shrivenham in the UK, Fort Leavenworth in the USA, and other European military staff colleges (Hodson, 2016). Exposure to international approaches to officer education allowed Irish officers to compare their

\footnotetext{
${ }^{1}$ The military decision-making process (MDMP) is an iterative planning methodology to understand the situation and mission develop a course of action, and produce an operation plan or order.
} 
education against international standards. On returning to the Defence Forces, these officers brought back the latest doctrinal and instructional approaches that served to drive changes to the Command and Staff Course syllabus. Accordingly, the Command and Staff School instructional staff have always been close to the cutting edge of curricular developments in senior officer education.

\section{Partnering with Maynooth University}

As internationally equivalent Command and Staff courses began to receive academic awards in the early 2000s, the Command and Staff School also explored the possibilities of developing an academic partnership with a higher education institute. Signal Magazine reported that "the Military College took the opportunity to co-operate with NUI Maynooth ${ }^{2}$ following a lengthy project to formulate a quality post-graduate programme" (SIGNAL, 2002, p. 73). Durnin (2003) believes that officers' experiences of working in multinational environments while deployed on PSOs influenced the decision to pursue accreditation. He also points out that "the aim is to ensure that the Irish course is of a similar high standard, so that the Military College can offer the same opportunity to our students, both Irish and International" (Durnin, 2003, p. 29). In a similar vein, Ryan (2012) identified that the motivation to develop a masters-level education for senior officers was driven by the desire to "put their course on a par with those of their international peers" (p. 54). Developments in international PME was a significant factor in driving changes to the Irish Command and Staff Course.

During discussions with Maynooth University staff, it was decided that a research module including a 12,000-15,000 word dissertation would be a requirement to bring the course to a masters-level education standard (Ryan, 2012). The research element was delivered and supervised by staff from the Department of Adult and Community Education and other departments. Radical adult education informed the research module and Maynooth University's pedagogical approach. This philosophy has three features that include:

(i) undertaking a critical interrogation of unexamined assumptions and beliefs as to how the world works; (ii) providing opportunities for students to draw on their personal and professional experiences to explore issues that are important to them; and (iii) actively involving all stakeholders in shaping the learning experience.

(Ryan, 2012, p. 57)

Partnering the Command and Staff School with the Department of Adult and Community Education at Maynooth University may have seemed like a strange decision at the time, as equivalent staff colleges typically established partnerships with international relations or defence studies departments. Radical pedagogy, however, with its associated research methodologies anchored in post-modernism and ideas about knowledge, proved suitable for Defence Forces' needs at that time. Post-modernism describes a world characterised by constant and rapid change, where old and familiar structures are irrelevant and where knowledge is constantly

\footnotetext{
${ }^{2}$ The National University of Ireland, Maynooth was rebranded in 2014 and was renamed Maynooth University.
} 
changing (Walsh, 2012). Considering that the world where the military operates is also characterised by uncertainty, a post-modern perspective offers much potential for educating people to operate in that world (Skootermany, 2017). This approach provided officers with the research tools and philosophies to interrogate personal and professional experiences. The research thesis process provided a safe academic space where organisational and professional areas of interest could be examined and interrogated in a scholarly way. From the inception of the academic partnership, successive courses have embraced the opportunity to research their professional context and have produced an invaluable body of research focused on a wide array of organisational areas. Research areas include leadership, defence and security policy, doctrine, international relations, human resource management, logistics, and gender issues, to name but a few.

Since 2003, the course has evolved and developed in response to changes in the strategic and operational environments to meet the ever-increasing educational needs of senior officers. The relationship between the Command and Staff School and Maynooth University has also evolved in the intervening period. The course is now co-delivered by academics from the Centre for Military History and Strategic Studies, and the Command and Staff School, bringing additional expertise in military history and defence studies to the existing strength in adult education pedagogies. Maynooth University also has embedded academic staff at the Command and Staff School to support the students and military staff.

To keep pace with changes in the operating environment, the Defence Forces must constantly evaluate how it trains and educates its personnel. Responding to the need to evaluate PME, the Deputy Chief of Staff (Operations) convened a joint working group in January 2017 to examine PME in the Defence Forces. A year later, the Working Group Report was presented to the General Staff for their consideration. The renaming and reorganisation of the Senior Command and Staff Course to become a Joint Command and Staff Course was one of its key recommendations. Arising from the Working Group's recommendations, the Command and Staff Course was redesigned in 2018 and renamed the Joint Command and Staff Course, and represents the latest version of senior officer education on offer in the Defence Forces. In the next section, an overview of the course and its associated modules is presented.

\section{The Joint Command and Staff Course}

The first Joint Command and Staff Course was conducted from August 2018 to June 2019. Currently, in its fourth iteration, the Joint Command and Staff Course has quickly established itself as the keystone of PME in the Defence Forces. The course is designed to ensure that the future leadership of the Defence Forces is capable of protecting and serving the state's interests both at home and overseas. The move to a Joint Command and Staff Course is also in line with the White Paper (2015) intention for the three services to operate jointly and "to deliver effects in operations in a coordinated and cohesive manner" (p. 61). Jointness, however, cannot happen effectively without being supported by a joint education. Keister, et al. (2014) point out that "the joint force has evolved from simple deconfliction to true operational synergy" (p. 71). The course 
presents an opportunity for students to understand better all military components, their capabilities, and the operational effects they can deliver.

The course aims to prepare mid-ranking officers to transition from the tactical level, to hold appointments at the operational, and strategic levels ${ }^{3}$. It is specifically designed to prepare senior officers for high-level assignments, including command, by developing their problem solving, critical thinking, decision-making and communication skills. The course focuses on broadening professional knowledge and understanding through a deeper appreciation of single service, joint, combined and multi-agency operations ${ }^{4}$. The ambition is to imbue officers with a better understanding of managing defence and security in the Irish political, social, economic, and foreign policy context.

\section{Course Overview}

The Joint Command and Staff Course runs for 41 weeks each year from August to June, preceded by an orientation course that prepares students for optimal course engagement. The course format is guided by the requirement to address all aspects of military engagement, action and function in contemporary and future operating environments. The defence functional framework informed the course design around the concepts of Ends, Ways and Means (DJ7, 2018). Ends relate to strategy and higher-level policy formulation; Ways is about campaigning and conducting operations; and Means focuses on balancing policy, capability, and resources. The Joint Command and Staff Course is the Defence Forces equivalent of the UK Advanced Command and Staff Course at the Joint Services Command and Staff College and the College Interarmee de Defence (CID) in Paris. Acknowledging the attributes of Ireland's role in the international system and the specific identity of the Defence Forces, the course also retains unique features that emphasise the role played by small states in the global security environment.

In order to ensure course cohesion and quality, the Command and Staff School has established partnerships with key national and international institutions such as the Institute of Public Administration, Cranfield University in the UK, and others to deliver select blocks of the course. In this way, the Joint Command and Staff Course offer senior officers a bespoke, internationally recognised, 90 ECTS credit course taught in partnership with Maynooth University and accredited by that institution. The course is delivered through seven modules related to the defence functional framework, with a brief description of the modules outlined in Table 1.

\footnotetext{
${ }^{3}$ Tactical level involves the application of combat power to achieve tactical objectives. The operational level is the level which major campaigns and operations are planned and conducted. The strategic level is the level where a nation or group of nations determine national security objectives and develop and use national assets to achieve these objectives.

${ }^{4}$ Single service relates to the use of one component of land, sea, or air. Joint operations refers to bringing together elements of the Army, Air Corps, and Naval Service to deliver effects in operations. Combined operations are when two services operate together. Multi-agency operations involves any of the three services in combination with other state entities such as the Gardai, Customs, and the HSE.
} 


\begin{tabular}{|c|c|c|c|}
\hline $\begin{array}{l}\text { Functional } \\
\text { Framework }\end{array}$ & Module & Credits & Description \\
\hline \multirow[t]{2}{*}{ Ends } & $\begin{array}{l}\text { Defence and } \\
\text { Strategic Studies }\end{array}$ & 10 & $\begin{array}{l}\text { This module aims to provide the student with a } \\
\text { post-graduate understanding of general theories } \\
\text { underpinning the origins of conflict, strategic } \\
\text { thought and international relations. }\end{array}$ \\
\hline & $\begin{array}{l}\text { Defence Research } \\
\text { Component }\end{array}$ & 30 & $\begin{array}{l}\text { The Defence Research Component develops the } \\
\text { students' knowledge and skills to design and carry } \\
\text { out their own research project in an area relevant } \\
\text { to their professional practice. This will culminate } \\
\text { with the submission of their Defence Research } \\
\text { Paper (15,000-word thesis). Completing this } \\
\text { research project will allow participants to reflect on } \\
\text { their practice or an area of relevance to the defence } \\
\text { field while promoting their research and critical } \\
\text { reflection skills. }\end{array}$ \\
\hline \multirow[t]{2}{*}{ Ways } & Component Studies & 5 & $\begin{array}{l}\text { The focus of this module is to provide the student } \\
\text { with an opportunity to practice the MDMP at } \\
\text { Brigade and Divisional level, exercise them in } \\
\text { planning combined and joint operations, and the } \\
\text { application of key doctrinal concepts with an } \\
\text { emphasis on the integration of land, maritime and } \\
\text { air components }\end{array}$ \\
\hline & $\begin{array}{l}\text { Operational Studies } \\
\text { \& Campaigning }\end{array}$ & 15 & $\begin{array}{l}\text { Operational Studies and Campaigning prepares } \\
\text { students to participate in joint operational planning } \\
\text { for warfighting and crisis management operations. } \\
\text { It expands the student's professional knowledge } \\
\text { through analysis of operational campaign studies. } \\
\text { Additionally, it exposes the student to the military } \\
\text { function at the operational level in joint, combined } \\
\text { and multi-agency environments. This module } \\
\text { culminates with a Joint Combined European } \\
\text { Exercise (CJEX), a two-week exercise conducted in } \\
\text { staff colleges around Europe in May each year. The } \\
\text { exercise allows students to practice the operational } \\
\text { planning process in multinational joint operational } \\
\text { planning groups. }\end{array}$ \\
\hline \multirow[t]{2}{*}{ Means } & Defence in Context & 10 & $\begin{array}{l}\text { This module aims to provide the student with a } \\
\text { post-graduate understanding of the organisation } \\
\text { and function of key international organisations and } \\
\text { the specific challenges they face. It explores how } \\
\text { strategy is formulated and applied for complex } \\
\text { multi-agency missions led by NATO, EU and UN. }\end{array}$ \\
\hline & $\begin{array}{l}\text { Defence Policy \& } \\
\text { Capability } \\
\text { Management }\end{array}$ & 10 & $\begin{array}{l}\text { This module aims to enhance the student's } \\
\text { understanding of the higher management of } \\
\text { defence nationally and internationally. It explores } \\
\text { the principles that govern the balancing of policy, } \\
\text { risk, and resources to deliver capability. }\end{array}$ \\
\hline
\end{tabular}




\begin{tabular}{l|l|l|l|l} 
Command, & $10 \quad \begin{array}{l}\text { Students are encouraged to evaluate and reflect on } \\
\text { Leadership and } \\
\text { Management }\end{array}$ & $\begin{array}{l}\text { Command, Leadership and Management } \\
\text { characteristics in all relevant contexts and } \\
\text { environments while incorporating individual } \\
\text { development and organisational awareness. }\end{array}$
\end{tabular}

Table 1. Course modules description (DJ7, 2018).

\section{Professional knowledge generation through research}

While post-modernism and radical pedagogy still influence the research and educational philosophy of the course, other ways of knowing and disciplinary approaches to conducting research are equally valued. This is evident in the new approach to the research module, where social science, arts and humanities, which have different associated methodologies and thesis structures, are supported within the research module. The guidance for thesis topics is broad so that students can research contemporary professional problems and produce findings and recommendations with "real-world" relevance following research traditions within the discipline (Maynooth University, 2020). A study of contemporary conflict or PSOs, for example, may offer new insights into problems of security, policy, or military doctrine. Equally, a work that studies past military practice, or historical battles and campaigns, can be used to shed light on contemporary problems and issues. The research possibilities are open-ended, which has broadened the scope for the research work that students can undertake on the course.

\section{Conclusion}

The Command and Staff School have been the vanguard of Defence Force education developments since the early 2000s. Their engagement with Maynooth University to deliver an accredited post-graduate level education for senior Defence Forces' officers was ground-breaking at the time. The MA in Leadership, Management and Defence Studies led the way for accredited learning throughout the organisation and has helped to achieve the policy objective of ensuring "that the educational and training outputs of the Defence Forces are in line with best international practice" (Department of Defence, 2015, p. 76).

The Command and Staff School, in collaboration with its academic partner Maynooth University and others, must continue to lead the way in evolving PME and research in the Defence Forces. PME for senior officers in the Defence Forces now provides a broader professional perspective and a richer learning experience than before. The Defence Forces engagement with higher education helps to provide that broader perspective. It has raised the overall education standard of serving personnel and has also helped to improve PME through the inculcation of higher education quality assurance standards on military courses. A constantly evolving, accredited joint education is a critical requirement for the Defence Forces to achieve strategic, operational and tactical synergies in uncertain operational contexts. 
One of the most significant achievements of the Defence Forces collaboration with Maynooth University for senior officer education has been the generation of new organisational knowledge through research. However, this knowledge needs to be harnessed and managed so that it can be used to help solve organisational problems. Clausewitz reminds us in On War, that "knowledge must become capability" (von Clausewitz, 1993). Therefore, the transformation of organisational knowledge into capabilities needs to become a tangible outcome for the organisation's investment in education.

Please note that the views expressed above represent those of the author alone and should not be taken to represent the views of the Department of Defence, the Irish Defence Forces or any other group or organisation.

\section{BIBLIOGRAPHY}

Barnett, R., 2012. Learning for an unknown future. Research and Development, Volume 31, pp. 65-77.

Barrett, J., 2009. Modern Developments in Defense Education. Connections, 8(2), pp. 1-6.

Cairns, L. \& Malloch, M., 2011. Theories of Work, Place and Learning: New Directions. In: M. Malloch, L. Cairns, K. Evans \& B. O' Connor, eds. The Sage Handbook of Workplace Learning. London: Sage Publications Ltd, pp. 3-16.

Callado-Munoz, F. J. \& Utrero-Gonzalez, N., 2019b. Integration in the European higher education area: the case of military education. Defence Studies, 19(4), pp. 373-391.

Davidson, P. \& Tsakissiris, J., 2020. Military education in the context of disruption. Australian Journal of Defence and Strategic Studies, 2(1), pp. 65-72.

Defence Forces, 2016. DFDM-L1 The Land Component. Dublin: Defence Forces Printing Press.

Defence Forces, 2021. military.ie. [Online]

Available at: https://www.military.ie/en/who-we-are/army/defence-forces-training-centre/themilitary-college/

[Accessed 8 April 2021].

Dempsey, M., 2011. US Army Learning Concept for 2015. [Online]

Available at: http://www.tradoc.army.mil/tpubs/pams/tp525-8-2.pdf

[Accessed 23 March 2017].

Department of Defence, 2015. The White Paper on Defence, Dublin: Department of Defence.

Department of Defence, 2019. White Paper on Defence Update, Dublin: Department of Defence.

DJ7, 2016. Syllabus of Training Senior Command and Staff Course, Dublin: Director of Training and Education Branch. 
DJ7, 2018. Syllabus of Training Joint Command and Staff Course, Dublin: Director of Defence Forces Training and Education Branch.

Durnin, J., 2003. Value Added Education. An Cosantoir, February(1), pp. 28-29.

European Union, 2003. European Security Strategy: A Secure Europe in a Better World, Brussels: EEAS Strategic Planning.

Foot, P., 2001. European Military Education Today. Baltic Defence Review, Volume 5, pp. 12-31.

Grint, K., 2005. Problems, problems, problems: the social construction of leadership. Human Relations, 58(11), pp. 1467-1494.

Head, B. W. \& Alford, J., 2015. Wicked problems: Implication for public policy and management. Administration and Society, 47(6), pp. 711-739.

Hodson, T., 2016. Establishing the Irish Military College. Defence Forces Review, pp. 103-110.

Hong, J., 1999. Structuring for organisational learning. The Learning Organization, 6(4), pp. 173186.

Jung, H., 2009. New ways of military thinking and acting for a better world: new models preparing forces to master unavoidable transitions. In: G. Caforio, ed. Advances in Military Sociology: Essays in Honor of Charles CMosokos (Contributions to conflict management, peace, economics and development. Bingley: Emerald Group Publishing Limited, pp. 353-393.

Keister, R., Slanger, R., Bain, M. \& Pavlik, D., 2014. Joint PME closing the gap for junior officers. Joint Forces Quarterly, Volume 3rd Quarter, pp. 65-71.

Kilcullen, D., 2009. The Accidental Guerrilla: Fighting Small Wars in the Midst of a Big One. New York: Oxford Univesity Press.

Libel, T., 2019. From the sociology of the (military) profession to the sociology of (security) expertise: the case of European national defence universities. Defence Studies, 19(1), pp. 62-84. Maynooth University, 2020. MA Research Handbook, Maynooth: Department of History. Minister of Defence, 2011. Army Doctrine Primer. Swindon: Army Doctrine Publication. Morgan-Owen, D., 2018. War on the Rocks. [Online] Available at: https://warontherocks.com/2018/07/approaching-a-fork-in-the-road-professionaleducation-and-military-learning/

[Accessed 11 May 2021].

Paananen, S. \& Pulkka, A.-T., 2019. Introduction. In: S. Paananen \& A. Pulkka, eds. Processes and Practices in Military Training and Education. Helsinki: National Defence University, pp. 1-3. Ryan, A., 2012. A Learning Partnership: NUI Maynooth and the Irish Defence Forces. In: T. Walsh, ed. Building a Better Future. Maynooth: Mace, pp. 52-63. 
Ryan, M., 2019. Extending the intellectual edge with artificial intelligence. Australian Journal of Defence and Strategic Studies, 1(1), pp. 23-40.

Sheehan, M., 2013. The Evolution of Modern Warfare. In: J. Baylis, J. J. Wirtz \& C. S. Gray, eds. Strategy in the Contemporary World. Oxford: Oxford University Press, pp. 60-75.

SIGNAL, 2002. Breaking the mould. SIGNAL Magazine, 1(2), pp. 73-78.

Skootermany, A. M., 2017. Military education reconsidered: A postmodern update. Journal of Philosophy of Education, 51(1), pp. 310-330.

Trefry, R. G., 1992. Soldiers and warriors; warriors and soldiers. In: C. Morris \& J. Morris, eds. The American Warrior. New York: Curtis Brown Ltd, pp. 50-51.

Utting, K., 2009. Beyond Joint - Professional Military Education for the 21st Century: The United Kingdom's Post-defence Training Review Advanced Command and Staff Course. Defence Studies, 9(3), pp. 310-328.

Vaill, P.B., 1996. Learning as a Way of Being: Strategies for Survival in a World of Permanent White Water. San Francisco: Jossey-Bass Publications.

von Clausewitz, C., 1993. On War. In: P. Paret \& M. Howard, eds. London: Everyman's Library. Walsh, T., 2012. Military Education for a Postmodern World. In: T. Walsh, ed. Building a Better Future. Maynooth: MACE, pp. 4-16. 